\title{
A LABOUR MODEL FOR SOUTH AFRICA
}

\author{
CHARLOTte DU TOIT AND ReneE KoEKemoer
}

SOUTH AFRICA'S PERFORMANCE has been dismal in dealing with the rising unemployment that the economy has been faced with since the 1970s. The purpose of this paper is to develop a labour model of the South African economy, which will be used in follow-up research to investigate the structural nature of the problem and to consider the question of whether the phenomenon of jobless growth is true for South Africa.

In this paper, a neoclassical labour market model of the South African economy is developed, distinguishing between a skilled and an unskilled labour market. The modelling of wages and employment is based on the systems approach followed by Layard and Nickell (1985, 1986) and Nickell (1988). They use a framework of wage bargaining under imperfect competition and, as a result, include the role of labour unions and labour taxes on employers.

The estimated labour model will be incorporated into a fullyfledged neoclassical supply-side model and linked to the macroeconometric model of the University of Pretoria in order to investigate empirically whether unemployment is mainly structural in nature. The analysis, although outside the scope of this paper, will entail both demand and supply-side policy scenarios in an attempt to evaluate the relative efficiency of various policy strategies in solving the problem.

\section{A LABOUR MODEL OF THE SOUTH AFRICAN}

ECONOMY Based on the official definition, the labour force survey (Stats SA: 2002) reports an unemployment rate in South Africa in the region of 29 per cent. This figure, according to the expanded definition, is 40.9 per cent. In order to test the hypothesis of whether this problem is primarily structural in nature and whether the South African economy indeed experiences jobless growth, it is necessary to develop a neoclassical labour model of the South African economy, where the 
resultant wage and employment levels influence economic activity through the supply side of the macro-econometric model.

For empirical purposes, the South African labour market is divided into two parts: a skilled and an unskilled labour market. The distinction is based on differences in the wage determination processes and differences in the demand for skilled and unskilled labour, which result from different levels of productivity and the role played by labour unions.

The work of Layard and Nickell $(1985,1986)$ and Nickell (1988) is used as reference to model wages and employment. They follow a systems approach to ensure consistency in a neoclassical framework and employ the principles of wage bargaining under imperfect competition, emphasising labour market interactions. Their approach also includes the role of labour unions and labour taxes on employers.

Fallon (1992) and Fallon and Perreira da Silva (1994) have done representative work on the South African labour market, analysing employment and wage behaviour and linking labour market policies to growth performance. Gibson (2000) investigates whether lower wages will cause faster growth in South Africa, and whether higher wages for unskilled workers will improve the distribution of income.

\section{(a) The theoretical framework}

\section{The labour market}

In modelling the labour market, a labour demand equation, a labour supply equation and a wage adjustment equation are defined and estimated. The labour market framework utilised in this study is based on the Layard-Nickell approach and is adapted from Whitley (1994). A significant distinction of this labour market framework is the incorporation of market imperfections, i.e. imperfect competition in goods markets and the role of unions in wage setting, thereby relaxing the issue of whether the market clears or not. The framework acknowledges the existence of an equilibrium rate of unemployment or the NAIRU, i.e. a non-accelerating inflation rate of unemployment.

Demand for labour is specified as: 
$N_{t}^{d}=f\left(w_{t}^{p}, Z_{t}^{d}\right)$

where $w^{p}$ is the real wage rate defined in terms of production prices, and $Z^{d}$ is a set of exogenous variables affecting the demand for labour. These might include the real prices of other factors of production, the capital stock, and output.

Labour supply is defined as:

$N_{t}^{s}=f\left(w_{t}^{c}, Z_{t}^{s}\right)$

Where $w^{f}$ is the real wage rate defined in terms of consumer prices, and $Z$ is a set of exogenous determinants such as the labour force, unemployment benefits and real interest rates.

Under market-clearing, the real wage rate $\left(w^{*}\right)$ is obtained by

solving the demand and supply equations, by setting demand equal to supply:

$w^{*}=f\left(T, Z^{d}, Z^{s}\right)$

where $\mathrm{T}$ is a set of tax variables causing a wedge between the real product wage and the real consumption wage. Market-clearing employment $\left(N^{*}\right)$ is given by:

${ }^{2}$ See Whitley (1994: 101-102) for an exposition on the NAIRU concept and how it is related to wage and price setting in an imperfectly competitive environment. 
$N^{*}=f\left(T, Z^{d}, Z^{s}\right)$.

In a disequilibrium framework, actual employment is typically determined as the minimum of the demand and supply $\left(N_{t}=\min \left(N_{t}^{s}-N_{t}^{d}\right)\right)$, and a wage adjustment mechanism is specified as:

$w_{t}-w_{t-1}=f\left[\left(N_{t}^{s}-N_{t}^{d}\right), Z_{t}^{w}\right]$

where $Z_{t}^{w}$ is a set of factors causing wages to deviate from their equilibrium values.

A reduced-form equation for the non-market-clearing model is:

$w_{t}=f\left(Z_{t}^{s}, Z_{t}^{d}, Z_{t}^{w}, T, w_{t-1}\right)$.

This is different from the market-clearing case (equation 3 ) due to the inclusion of $Z^{\nu}$ and $w_{t, 1}$.

The reduced-form representation of employment in the non-marketclearing case is:

$$
N_{t}=f\left(Z_{t}^{s}, Z_{t}^{d}, Z_{t}^{w}, T, w_{t-1}\right) \text {. }
$$

The labour force (L) may be treated as exogenous or explained by a participation equation. Both instances allow changes in employment to be directly associated with changes in unemployment:

$U_{t}=L_{t}-N_{t}$.

In practice, the excess supply of labour is proxied by the level of unemployment $(U)$, giving:

$w_{t}-w_{t-1}=f\left(U_{t}, Z_{t}^{w}\right)$

which closely resembles the augmented Phillips curve:

$$
w_{t}-w_{t-1}=f\left(U_{t}, P_{t}^{e} \mid P_{t-1}, Z_{t}^{w}\right)
$$

where $P^{f}$ is the expected price level. The Phillips curve, i.e. the 
relationship between inflation and unemployment, is therefore embodied in the dynamic adjustment mechanism to equilibrium.

The demand for labour

For purposes of consistency between factor demands and price setting, these equations and every decision about the supply of output ought to be derived jointly. Nickell (1988) argues that if this consistency is not present, the equilibrium level of employment consistent with the NAIRU may not correspond with that given by the labour demand function conditioned on equilibrium real wages. For this reason, Layard and Nickell \{op. at) suggest the cost function approach as opposed to the production function approach be used to derive factor demands.

For the purpose of generating a measure for capacity utilisation, the development of the neoclassical supply side prior to this study followed an approach where the cost function was directly estimated and then utilised to derive a consistent production function based on the principles of Shephard's duality. This approach ensures consistency between factor demands and the price setting mechanisms. The factor demands are now derived from a production function that is consistent with the underlying cost structures of the economy.

The approach can be summarised as follows: Assume a production function of the general form:

$$
y=y(n, k, t)
$$

where $y$ is output, $n$ is employment, $k$ capital stock and $t$ technology. The labour demand function can be derived by rearranging the marginal productivity condition for labour under profit maximisation. A firm ensures profit maximisation by employing workers up to the point where the real wage equals the marginal product of labour:

$$
w / p=y_{n}(n, k, t) \text {. }
$$

\footnotetext{
See Du Toit (1999).
} 
Rearranging and substituting capital with the production function yields:

$$
n^{d}=n^{d}(w / p, y, t) \text {. }
$$

Assuming a Cobb-Douglas technology then gives:

$$
n^{d}=\alpha y \cdot(w / p)^{-1}
$$

with $\alpha$ the labour elasticity of production.

labour supply

In order to derive a consistent model for unemployment, the supply of labour is specified as:

$$
N_{t}^{s}=E A P_{t} * L F P_{t}
$$

where $E A P$ is the economically active population, defined as that part of the population between the age of 15 and 65 that is eligible to work, and $L F P$ represents the labour force participation rate.

The rate of labour force participation is defined as:

$$
L F P_{t}=f\left(w_{t}^{c}, Z_{t}^{s}\right)
$$

where $w^{\mathscr{V}}$ is the real wage rate defined in terms of consumer prices, and $Z^{s}$ is a set of exogenous determinants of labour supply, including unemployment benefits, the role of labour unions; and real interest rates.

\section{Wage determination}

For purposes of closing the labour model, it is necessary to specify a model for wage determination, consistent with the rest of the supply side.

As Nickell ( $p p$. at.) pointed out, a wage function has to be sufficiently general to encompass every possible mechanism of wage determination, i.e.: (1) supply and demand factors; (2) firms' profitmaximising and cost-minimising behaviour; (3) the role of unions and (4) processes of collective bargaining.

The wage determination model that is proposed and utilised 
here, is based on a union bargaining framework and assumes imperfect competition in goods markets. The framework is extended to incorporate the role of taxes that create a wedge between the real product and the real consumption wage.

Firms are assumed to bargain over wages in order to maximise their expected real profits,

$\pi_{i}^{*}=\frac{P_{i}}{P^{e}} Y_{i}-\frac{W}{P^{e}} N_{i}$

where $P_{i}$ is the mark-up price the firm sets, $P^{\epsilon}$ is the expected aggregate production price level, $Y_{i}$ is the firm's output, $W$ the nominal wage and $N_{i}$ the labour demanded by the firm.

Expected real profits can be written as a function with the form:

$$
\pi_{i}^{*}=\pi_{i}\left(W / P^{e}, Y^{*} / \alpha L\right) K_{i}
$$

where $Y^{*}$ denotes expected demand and $K_{i}$ capital stock.

A union, representing the labour force associated with a certain firm $\left(L_{i}\right)$,is assumed to bargain over wages in order to maximise it's utility $\left(U_{i}\right)$ :

$U_{i}=N_{i} v+\left(L_{i}-N_{i}\right) \bar{v}$

where $v$ is a union member's utility if he is employed within the firm, and $\bar{v}$ is his utility if not.

The union member's utility functions may be written as:

$v=v\left(W_{c} / P_{c}^{e}\right)$

and

$\bar{v}=\bar{v}\left(W_{c} / P_{c}^{e}, N / L, \tau_{2}\right)$

where $W_{c}$ is the consumption after-tax wage and $P_{c}^{e}$ is expected

$4 \quad$ See Nickell (1985) for an exposition and derivation of the equation. 
consumer prices, denoting $W_{c} / P_{c}^{e}$ as the real consumption after-tax wage; $z_{2}$ denotes those variables that improve the worker's welfare while unemployed, e.g. the replacement ratio (or unemployment benefit relative to income).

The real consumption wage $\left(W_{c} / P_{c}^{e}\right)$ is dependent on the real product wage $\left(W / P^{*}\right)$ and the wedge between the two. These wedge elements consist of (1) taxes that change product relative to consumption wages, e.g. employers' labour taxes, employees' income taxes and taxes on consumption goods; and (2) the real price of imports $\left(P_{m} / \bar{P}\right) .{ }^{5}$ Equations (20) and (21) can therefore be written as:

$v=v\left(W / P^{e}, z_{t}, P_{m} / \bar{P}\right)$

and

$$
\bar{v}=\bar{v}\left(W / P^{e}, \tau_{1}, P_{m} / \bar{P}, \tau_{2}, N / L\right)
$$

where $z_{1}$ is the taxation element of the wedge.

Since employment $\left(N_{i}\right)$ can be written as a function of the form:

$$
N_{i}=N_{i}\left(W / P^{e}, Y^{*} / \alpha L\right) K_{i}
$$

the union's utility function can be written as:

$$
U_{i}=(v-\bar{v}) N_{i}\left(W / P^{e}, Y^{*} / \alpha L\right) K_{i}+\bar{v} L_{i} .
$$

The wage function, resulting from a union-firm wage bargaining model such as that proposed by Nash (1950), is of the form:

$$
W / P^{e}=w\left(Y^{*} / \alpha L, N / L, z_{1}, z_{2}, P_{n} / \bar{P}\right)
$$

Nickell (1985) proposes a separation between exogenous and

$5 \quad \bar{P}$ denotes the price of domestic output (not value added). See Nickell (1985) for an exposition and derivation of the equation. 
endogenous elements. It is therefore useful to rewrite $P_{n} / \bar{P}$ as $\left(P_{m} / P^{*}\right)\left(P^{*} / \bar{P}\right)$, where $P_{m} / P^{*}$ can be said to be the exogenous international terms of trade and $P^{*} / \bar{P}$ the endogenous level of competitiveness.

Including a measure for union power $\left(U_{D}\right)$ ), which is positively related to real wages, the wage equation can finally be written as:

$W / P=w\left(Y^{*} / \alpha L, N / L, P^{*} / \bar{P}, \approx\right) P^{*} / P$

with $\mathrm{z}$ the complete set of exogenous wage pressure variables:

$z=\left(z_{1}, \tau_{2}, P_{m} / P^{*}, U_{p}\right)$.

(b) The empirical model

For purposes of consistency between the factor demands and price setting mechanisms within a neoclassical framework where firms' decision-making processes are aimed at profit making, these equations are jointly determined. Imperfect competition in the goods markets and the role of labour unions in the price setting process are modelled.

A Cobb-Douglas cost function was estimated and validated as representative of the South African production structure and utilised to derive a consistent production function based on Shephard's duality principles. A production function is therefore used to derive the demand for labour within a framework of profit maximisation. A distinction is made between the demand for skilled and unskilled labour. Based on the theoretical exposition in the previous section, the demand for skilled labour $\left(N_{s}^{d}\right)$ is specified and estimated as:

$N_{s}^{d}=f\left(y,\left(w_{s} / w_{u}\right)\right)$

+ where $y$ is real output and $\left(w_{s} / w_{u}\right)$ denotes the skilled relative to unskilled wage rate.

\footnotetext{
See Du Toit (1999).
} 
The demand for unskilled labour $\left(N_{*}^{d}\right)$ is specified and estimated as:

$N^{d}=f\left(y, w_{u}\right)$

where $w_{u}$ is the nominal unskilled wage rate.

Labour supply is also divided into skilled and unskilled workers. Based on the availability of reliable data, total and skilled labour supply are estimated and used to derive the supply of unskilled labour.

Although total labour supply $(N)$ is specified as: $N^{s}=E A P * L F P$ with $L F P=f\left(w^{c}, Z^{s}\right)$, it is estimated in the form:

$N^{s}=f\left(w^{c}, E A P, Z^{s}\right)$

where $E A P$ is the economically active population. The set of exogenous determinants of labour supply $(Z)$ such as unemployment benefits, the role of labour unions and international competitiveness, are mainly included in the short-run estimation of the model.

The supply of skilled labour $\left(N_{s}^{s}\right)$ may be defined as $N_{s}^{s}=N^{s} *$ share $_{s}$, with share $=f\left(w^{c}\right.$, educ $)$ where share, denotes the share of skilled labour in the total labour supply and $e d u c$ refers to the level of education.

Skilled labour supply $\left(N_{s}^{s}\right)$ is estimated by:

$$
N_{s}^{s}=f\left(w_{s}^{c}, e d u c, N^{s}\right)
$$

with $N^{s}$ only included in the short-run dynamics of the model. 
Wage functions, consistent with the neoclassical cost-minimising approach and based on the Layard-Nickell framework, were specified for both the skilled and unskilled labour markets.

The skilled wage rate $\left(w_{s}^{c}\right)$ is specified and estimated as:

$w_{s}^{c}=f\left(\right.$ Urate, product $\left._{n}\right)$

where $w_{s}^{c}$ denotes the real consumer skilled wage rate, Urate is the

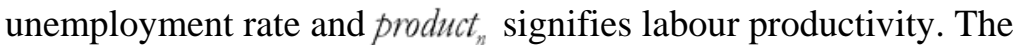
other explanatory variables specified in the Layard-Nickell framework are included in the short-run dynamics of the wage model.

The unskilled wage rate $\left(w_{u}^{c}\right)$ is specified and estimated as:

$$
w_{u}^{e}=f\left(\text { Urate, } \text { product }_{n}\right)
$$

where $w_{u}^{c}$ is the real consumption unskilled wage rate and, as before, Urate is the unemployment rate and product ${ }_{n}$ signifies labour productivity. Similar to the model of skilled wages, the other explanatory variables included in the short-run dynamics of the wage function are those specified in the Layard-Nickell framework.

\section{EMPIRICAL ESTIMATION RESULTS (a)}

The data

The sources and construction of the data series used to estimate the theoretical model above empirically, as well as the univariate characteristics of the data, are discussed in Appendix 1. All data series were employed in first differenced form in error correction models, thus being considered to be integrated of order 1 . The sample period is 1970 to 2000. 


\section{(b) Estimation technique}

A single equation residual based estimation procedure was chosen , despite well-known potential defects. This methodology entails the determination of the long-run relationship through testing for stationarity of the residuals, employing an Augmented Dickey-Fuller test. If the null hypothesis of no cointegration can be rejected, calculating the $p$ percent critical values using response surface analysis (MacKinnon 1991:273-75), ${ }^{9}$ an error correction model can be estimated, containing both the long-run cointegration equation lagged by one period (called the error correction mechanism) as well as the short-run dynamic structure allowing for adjustment towards equilibrium.

\section{(c) Estimation results}

In this section the empirical estimation of the theoretical labour market model set out in the previous section is discussed. Six behavioural equations are reported, namely demand for skilled labour (ns), demand for unskilled labour (nu), total labour supply (j), skilled labour supply (ss), the real skilled wage rate, cpi deflated (wsratecpi), and the real unskilled wage rate, cpi deflated (wuratecpi). Total labour demand is determined as the total of the skilled and unskilled labour demand. Unskilled labour supply can be derived from total labour supply and skilled labour supply.

A number of conventions apply with regard to reporting of results. Lower-case letters indicate natural logs, and A indicates a first difference. Each relationship is written to distinguish the long-run solution of the equation from the short-run dynamics.

\footnotetext{
8 In a macro-modelling context, single equation estimation is still widely used by practitioners; see Bank of England (2000) for a description of modelling tools used to assist the Monetary Policy Committee in their modelling activities. More specifically, see labour market estimation (op .at.: 36-54).

9 The response surface for any number of regressors, excluding; any constant and trend components, $1 \leq \mathrm{n} \leq 6$, can be calculated as $C(p)=\phi_{\infty}+\phi_{1} T^{-1}+\phi_{2} T^{-2}$, where

$C(p)$ is the $p$ percent critical value.
} 
Long-run solutions appear in square brackets, and follow from the usual practice of estimating error correction models. T-statistics are included in parentheses below coefficients. A standard set of diagnostic tests is shown. Probability values for the diagnostic tests (the probability of falsely rejecting the null hypothesis of a zero restriction on the coefficient or diagnostic) are given in square brackets.

Diagnostic statistics throughout suggest that equations are statistically well-specified, with no violations of the classical assumptions. BJ denotes the Bera-Jarque test for the normality assumption; LB and LM denote tests for serial correlation; Ramsey's RESET is a test for misspecification and ARCH and White denote tests for the homoscedasticity assumption. All tests are distributed $\chi^{2}$, with figures in parentheses denoting degrees of freedom. Recursive estimates also confirmed stability in the parameters throughout.

Demand for skilled labour

Skilled labour demand in the long run is specified and estimated in terms of real output and the skilled relative to unskilled wage rate. A dummy variable accounting for affirmative action legislation, being equal to 1 from 1995 onwards, as well as a dummy variable capturing the more extensive labour legislation (Employment Equity Act, etc) from 1999 onwards, were also included in the long-run cointegration equation.

Given the large degree of openness of the South African economy, international factors (denoted by an index intpos) such as the exchange rate, foreign investment, level of domestic and international competitiveness, share in world trade and the gold price, also influence the short-run dynamics of the system. 


$$
\begin{aligned}
& \Delta n s_{t}=0.0053+0.48 \Delta g d p_{t}-0.39 \Delta \text { wsrate }_{t}+0.38 \Delta \text { wrute }_{t} \\
& \text { (0.46) (4.33) (-5.93) (5.30) } \\
& -0.04 \Delta \text { intpos }_{t} \\
& (-2.96) \\
& -0.43\left[n s_{t-1}-9.17-0.52 g_{d p}+0.46 \text { wsrate }_{t-1}\right. \\
& (-2.24) \\
& -0.51 \text { murate }_{t-1}+0.04 \text { dum }_{t-1}-0.05{\text { dum } \left.2_{t-1}\right]}
\end{aligned}
$$

Adjusted R2: 0.78

Equation standard error: 0.0127

Normality test: $\mathrm{BJ}(2)=0.949[0.662]$

Serial correlation: $\mathrm{LB}(8)=4.923$ [0.776]; $\mathrm{LM}(2)=0.749$ [0.688]

Heteroscedasticity: ARCH(1) = 1.441 [0.229]; White $(\mathrm{l})=11.929$ [0.289]

Stability: $\operatorname{RESET}(2)=1.215[0.545]$

ADF10: : -3.44

where

$n s=$ demand for skilled labour (skilled employment)

$g d p=$ gross domestic product at constant 1995 prices

wsrate - nominal skilled wage rate (ivs/ns)

wurate - nominal unskilled wage rate $(\mathrm{im} / \mathrm{nu})$

intpos $=$ international position index

duml — dummy denoting affirmative action ( 0 up to 1994, 1 thereafter)

dum2 - dummy reflecting more extensive labour legislation

(1999, 2000 =1,0 otherwise)

\section{Demand for unskilled labour}

The demand for unskilled labour in the long run is specified and estimated in terms of real output and the nominal rather than the real product unskilled wage rate - on the plausible assumption that employers are foremost concerned about the impact of the wage bill of unskilled employees on the company's cash flow situation, especially against the background of increased and costly

\footnotetext{
10 Unit root test on the residual of long-run equilibrium equation.
} 
labour legislation.

In addition, short-run dynamics are explained by socio-economic factors (denoted by an index socind) such as the level of education, and the provision of housing and basic services such as electricity, the crime rate, levels of disposable income, unemployment benefits and other government transfers. All these have a significant effect on the efficiency of labour in South Africa.

$$
\begin{gathered}
\Delta n u_{t}=-0.0214+0.38 \Delta g d p_{t}+0.11 \Delta \text { wun }_{t}-0.27 \Delta \text { socind }_{t} \\
(-2.44)(3.30) \quad(1.77) \quad(-3.42) \\
-0.40\left[n u_{t-1}-3.35-0.86 \mathrm{gdp}_{t-1}+0.14 \text { wurate }_{t-1}\right. \\
\quad+0.06{\text { dum } 1_{t-1}}+0.07{\text { dum } \left.2_{t-1}\right]}^{(-3.09)}
\end{gathered}
$$

Adjusted R2:0.58

Equation standard error: 0.0135

Normality test: $\mathrm{BJ}(2)=0.001[0.999]$

Serial correlation: $\mathrm{LB}(8)=2.585$ [0.958]; $\mathrm{LM}(2)=0.827$ [0.661]

Heteroscedasticity: ARCH(l) =2.035 [0.154]; White $(\mathrm{l})=15.959$ [0.043]

Stability: RESET(2) $=3.988[0.136]$

ADF: -6.13

where

$n u$ — demand for unskilled labour (unskilled employment)

$g d p=$ gross domestic product at constant 1995 prices

wurate - nominal unskilled wage rate $(\mathrm{im} / \mathrm{nu})$

socind - socio-economic index

wun - nominal unskilled wage bill

duml - dummy denoting affirmative action (0 up to 1994, 1 thereafter)

dum2 - dummy reflecting more extensive labour legislation

(1999, $2000=1,0$ otherwise)

\section{Total labour supply}

Labour supply is also divided into skilled and unskilled workers. Based on availability of reliable data, total and skilled labour supply are estimated and used to derive the supply of unskilled 
labour.

Although total labour supply theoretically is specified in terms of the economically active population and labour force participation (with labour force participation defined in terms of the real consumption wage rate and a set of exogenous determinants), it is estimated in one equation. Total population is used to proxy the economically active population.

As a result, the structural equation for total labour supply is estimated in terms of the total population, the total real consumption wage rate and dummy variables capturing affirmative action legislation since 1995 and the period of economic sanctions against South Africa between 1985 and 1994. Affirmative action legislation presumably improved the accessibility of the South African labour market for unskilled workers, which is by far the larger component of the total labour force, while the period of economic sanctions diminished the access of especially skilled workers to the international labour market and who had to seek jobs nationally.

The supply of labour in the short run is influenced by those variables determining the potential of the economy to increase the labour absorption capacity, i.e. the availability of job opportunities. In this respect it is plausible to assume that total labour supply in the short run is dependent on a set of international factors (denoted by an index intpos) such as the exchange rate, foreign investment, level of domestic and international competitiveness, share in world trade and the gold price.

$$
\begin{aligned}
\Delta s_{t}= & 0.70 \Delta \text { popt }_{t}+0.003 \Delta \text { intpos }_{t}+0.36 \Delta s_{t-1} \\
& (4.63) \quad(2.19) \quad(2.64) \\
& -0.07\left[s_{t-1}-0.97 \text { pop }_{t-1}-0.11 \text { wratecpi }_{t-1}\right. \\
& (-1.80) \\
& \left.-0.02 \text { dum }_{t-1}-0.01 \text { sancdum }_{t-1}\right]
\end{aligned}
$$

Adjusted R²:0.83 
Equation standard error: 0.0011

Normality test: $\mathrm{BJ}(2)=2.55[0.879]$

Serial correlation: $\operatorname{LB}(8)=10.086[0.259] ; \operatorname{LM}(2)=4.160[0.125]$

Heteroscedasticity: ARCH(l) $=0.009$ [0.921]; White(1)=4.543 [0.805]

Stability: RESET(2) $=0.028[0.986]$

ADF: -3.02

where

$s=$ total labour supply

pop $=$ total population

intpos - international position index

wratepi - total wage rate at constant 1995 prices, CPI deflated

duml - dummy denoting affirmative action (0 up to 1994, 1 thereafter)

sancdum $=$ dummy denoting the period of economic sanctions against

South Africa (1985-1994=1, 0 otherwise)

Skilled labour supply

The supply of skilled labour is defined as the share of skilled labour in the total labour supply, where the share of skilled labour is dependent on the real consumption wage rate and the level of education. The supply of skilled labour was estimated in a single equation with skilled labour supply a function of the real consumption wage rate, the level of education and a dummy variable presenting the period of economic sanctions against South Africa - as described above.

The significance of the level of education as an explanatory variable emphasises the importance of government policies directed towards skills development and education as a solution to the severe unemployment and poverty problems of the South African economy.

The dummy variable for affirmative action legislation since 1995 also proved to be a significant explanatory variable for the short-run dynamics of the supply of skilled labour. 


$$
\begin{aligned}
\Delta s s_{t}= & 2.10 \Delta p o p_{t}-1.94 \Delta p o p_{t-2}+0.88 \Delta s s_{t-1}+0.03 \text { dum }_{t} \\
& \text { (2.16) (-2.14) (8.75) (3.87) } \\
- & 0.04\left[s s_{t-1}-18.16-0.51 \text { educ } 95_{t-1}\right. \\
& (-1.95) \\
& \left.-0.83 \text { wsratecpi }_{t-1}-0.10 \text { sancdum }_{t-1}\right]
\end{aligned}
$$

Adjusted R2: 0.81

Equation standard error: 0.0069

Normality test: $\mathrm{BJ}(2)=39.169[0.000]$

Serial correlation: $\mathrm{LB}(8)=2.140$ [0.976]; $\mathrm{LM}(2)=1.437$ [0.487]

Heteroscedasticity: ARCH(l) $=0.0003$ [0.986]; White(l) $=10.504$ [0.311]

Stability: RESET(2) $=0.514$ [0.773]

ADF: -3.02

where

ss = skilled labour supply

educ95 - education index

pop - total population

wsratepi - skilled wage rate at constant 1995 prices, CPI deflated

dum1 - dummy denoting affirmative action (0 up to 1994, 1 thereafter)

sancdum = dummy denoting the period of economic sanctions against

South Africa (1985-1994=1, 0 otherwise)

\section{Skilled wage rate}

According to Layard and NickelPs non-market clearing model, wages should, in general, include variables such as labour productivity, the unemployment rate, levels of domestic and international competitiveness and a set of exogenous variables explaining (1) the taxation element of the wedge between consumption and product wages, and (2) variables that improve workers' welfare while unemployed.

In line with this, the skilled wage rate in the long run is specified and estimated in terms of the unemployment rate, labour productivity and, once again, the dummy variable depicting affirmative action legislation. In addition, the short-run dynamics 
of the system are explained in terms of a set of socio-economic factors (denoted by an index socind) like the level of education, provision of housing and basic services (such as electricity), the crime rate, levels of disposable income, unemployment benefits and other government transfers, all of which have a significant affect on the efficiency of labour in South Africa.

Another short-run explanatory variable is the role of labour unions in South Africa (denoted by an index unionind). By lobbying for affirmative action legislation and other related labour legislation, that would narrow the wage gaps created by the Apartheid regime, they are successful in impacting negatively on skilled wages.

And finally, the level of economic activity, represented by real output ( $g d p$ ), also significantly impacts on the short-run dynamics of the skilled wage rate.

$$
\begin{aligned}
& \Delta \text { wratecpi } i_{t}=0.45 \Delta \text { v sratecpi }_{t-1}-0.19 \Delta \text { urate }_{t}+0.46 \Delta \text { urate }_{t-1} \\
& \text { (3.27) (-2.08) (4.39) } \\
& -0.18 \text { urate }_{t-2}+1.07 \text { 4prod } 95_{t-1}-0.35 \text { 4socind }{ }_{t-1} \\
& \text { (-1.88) (3.68) (-2.09) } \\
& -0.05 \text { Aunionind }_{t}-0.08 \text { _unionind }_{t-1}+0.90 \Delta \mathrm{dgdp} \text { t }
\end{aligned}
$$

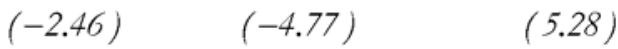

$$
\begin{aligned}
& -1.19 \Delta g d p_{t-1} \\
& (-3.76) \\
& -0.18\left[\text { w sratecpi }_{t-1}+0.87 \text { urate }_{t-1}-5.88 \text { prod } 95_{t-1}\right. \\
& (-3.74) \\
& \left.+0.41 \text { dum }_{t-1}\right]
\end{aligned}
$$

Adjusted R2: 0.72

Equation standard error: 0.0158

Normality test: $\mathrm{BJ}(2)=10.433[0.005]$

Serial correlation: $\mathrm{LB}(8)=6.146$ [0.613]; $\mathrm{LM}(2)=2.428$ [0.297]

Heteroscedasticity: ARCH(1) $=0.588$ [0.443]; White $(\mathrm{l})=23.776$ [0.359]

Stability: RESET(2) $=3.058[0.217]$

ADF: -3.34 
where

wsratepi - skilled wage rate at constant 1995 prices, CPI deflated

urate - unemployment rate

prod95 = labour productivity igdp/ti)

unionind - union pressure index

$g d p=$ gross domestic product at 1995 prices

socind - socio-economic index

dum1 — dummy denoting affirmative action (0 up to 1994, 1 thereafter)

Unskilled wage rate

Similar to skilled wages, the unskilled wage rate in the long run is specified and estimated in terms of the unemployment rate, labour productivity and a dummy variable capturing the effects of affirmative action legislation. The sign of the affirmative dummy in the case of the unskilled wage rate suggests that labour unions were unsuccessful in their attempts to inflate unskilled wages through affirmative policies. This notion can be supported by the unstable and unprofitable environment, particularly for skilled labour in South Africa, that resulted from these policies. It presumably contributed to the outflow of highly qualified and professional labour, negatively impacting on entrepreneurial skills and subsequently diminishing job opportunities for unskilled labour.

Short-run dynamics are explained by a set of socio-economic factors (denoted by an index socind), which influences the efficiency of, particularly, unskilled labour. The unskilled wage rate in the short run is also dependent on a set of international factors (denoted by an index intpos) such as the exchange rate, foreign investment, level of domestic and international competitiveness, share in world trade and the gold price. Apart from the fact that these international factors contribute to production activities and therefore employment opportunities in the economy, it is of interest to note that the mining industry in particular, presumably had a severe impact on unskilled wages since the early 1980s. The real value of South African gold exports 
slumped dramatically due to a declining international interest in gold and a sharp decrease in the gold price. It resulted in a slowdown in the demand for, particularly, unskilled labour, resulting in a slowdown in unskilled wages.

$$
\begin{aligned}
& \Delta \text { vuratecpi }_{t}=-0.49 \Delta \text { prod } 95_{t-1}+0.76 \Delta \text { socind }_{t}-0.07 \text { Bintpos }_{t-1} \\
& (-1.77) \quad(5.64) \quad(-2.59)
\end{aligned}
$$

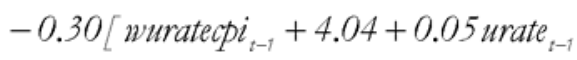

$$
\begin{aligned}
& (-3.29) \\
& \left.-2.18 \operatorname{prod} 95_{t-1}+0.16 \text { dumt }_{t-1}\right]
\end{aligned}
$$

Adjusted R²: 0.51

Equation standard error: 0.0276

Normality test: $\mathrm{BJ}(2)=0.803[0.669]$

Serial correlation: $\operatorname{LB}(8)=4.465$ [0.813]; $\mathrm{LM}(2)=1.011[0.604]$

Heteroscedasticity: ARCH(1) $=0.083$ [0.773]; White $(\mathrm{l})=12.607$ [0.126]

Stability: RESET(2) $=5.686[0.058]$

ADF: -3.96

where

wuratecpi - skilled wage rate at constant 1995 prices, CPI deflated

urate - unemployment rate

intpos - international position index

prod95 = labour productivity igdp/ti)

sorind $=$ social-economic index

dum1 — dummy denoting affirmative action (0 up to 1994, 1 thereafter)

\section{CONCLUSIONS}

From analysing the labour market in South Africa, it is clear that it has not performed its allocative, distributional and information functions efficiently, as may be seen against the backdrop of the alarming levels of unemployment in the economy and the virtual disappearance of the economy's capacity to create jobs for a growing labour force.

The main factors that seriously influence the labour market are government interventionist actions, aggressive trade union 
activities, minimum wage arrangements, exorbitant social benefit packages of workers, inadequate skills and training of workers, inappropriate production technologies and low productivity. These shortcomings are arguably structural in nature and have a direct bearing on severe poverty and the very skewed distribution of income. These factors have to be taken into account in any package of policy proposals.

The purpose of this paper was to develop a labour market model of the South African economy. The model comprises six behavioural equations, namely the demand for skilled labour, the demand for unskilled labour, total labour supply, the skilled labour supply, the real skilled wage rate and the real unskilled wage rate, both CPI deflated. Total labour demand is determined as the total of the skilled and unskilled labour demand. Unskilled labour supply can be derived from total labour supply and the skilled labour supply. All estimated equations were subjected to rigorous diagnostic testing.

The estimated model will be used in follow-up research to test the hypothesis of structural unemployment empirically and will also make it possible to derive a measure of the NAIRU (non-accelerating inflation rate of unemployment) or NAWRU (non-accelerating wage rate of unemployment), which in a full-sector macro model will feed through potential output, capacity utilisation and prices. Although outside the scope of this paper, such a measure will therefore also contribute towards the analysis of the structural nature of unemployment in South Africa.

\section{APPENDIX 1:}

Sources of Data and Calculations

The sources and construction of the data series used to empirically estimate the theoretical model above are discussed in this section, as well as the univariate characteristics of the data.

Data series employed in empirical estimation are listed in Table Al. Sources of data include the South African Reserve Bank, Stats SA, the Development Bank of Southern Africa, and Trade and Industrial Policy Strategies (TIPS) from whom labour market data were obtained. 
Table A1. List of variables

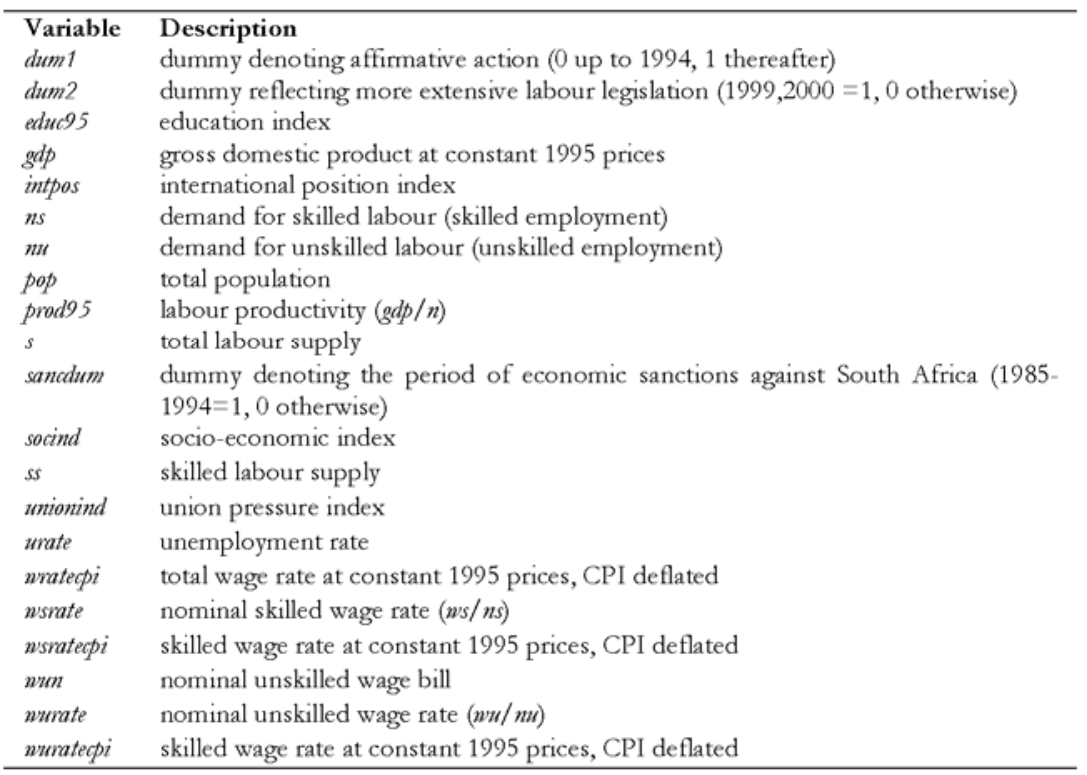

Order of integration

In analysing the univariate characteristics of the data, the Dickey-Fuller (DF) and Augmented Dickey-Fuller tests were employed to establish the order of integration of data series, all variables in natural logarithmic form. The testing strategy is as suggested by Dolado et al. (1990). (Also see Enders (1995:257)).

The number of lags used in the estimated equations was determined in a similar way as suggested by Perron (1989:1384), namely starting with eight lags and testing downwards, until the last lag is significant or there are no lags left.

Tables A2 and A3 report the outcomes of the ADF-tests for all relevant data series employed in the estimations. The series tested are listed in the first column. The second column reports whether a trend and a constant (Trend), only a constant (Constant), or neither one (None) is reported. The next column shows the ADF t-statistic, called $T_{T}$ when a trend and a constant are included, $\tau_{\mu}$ when only a constant is included, and $\mathrm{T}$ when neither is included. The last column reports the F-statistic, $\Phi_{3}\left(\Phi_{1}\right)$, testing

whether the trend (constant) is significant under the null hypothesis of no unit root.

According to Table A2, ADF-tests render some of the wage variables stationary in levels, e.g. the skilled and unskilled wage rates as well as skilled labour demand. However, upon visual inspection of graphical representations of the series and inspection of the relevant correlograms, it is clear that these variables cannot be stationary in levels. All variables are therefore considered to be integrated of order 1 (see Table A3). 
Table A2. Augmented Dickey-Fuller Tests for Non-Stationarity, Levels, 1970-1999

(All data series in natural logarithmic form)

\begin{tabular}{|c|c|c|c|c|}
\hline Series & Model & Lags & $\tau_{\tau}, \tau_{\mu} \tau^{a}$ & $\Phi_{3}, \Phi_{1}^{\mathrm{b}}$ \\
\hline \multirow[t]{3}{*}{ edves } & Trend & 0 & 3.25 & \\
\hline & Constant & 4 & 0.24 & 1.89 \\
\hline & None & 5 & -1.65 & \\
\hline \multirow{3}{*}{$g d p$} & Trend & 0 & -2.33 & 4.55 \\
\hline & Constant & 0 & -2.36 & 5.17 \\
\hline & None & 1 & 2.51 & \\
\hline \multirow[t]{3}{*}{ intpos } & Trend & 0 & 1.58 & 3.72 \\
\hline & Constant & 0 & -1.79 & 3.23 \\
\hline & None & 0 & -1.72 & \\
\hline \multirow[t]{3}{*}{$n s$} & Trend & 3 & -0.78 & 13.89 \\
\hline & Constant & 3 & $-3.07^{*}$ & $12.26^{* *}$ \\
\hline & None & 5 & -1.27 & \\
\hline \multirow[t]{3}{*}{$n x$} & Trend & 1 & -3.07 & $9.08^{*}$ \\
\hline & Constant & 1 & -2.29 & $10.14^{*}$ \\
\hline & None & 2 & -0.84 & \\
\hline \multirow[t]{3}{*}{$p o p$} & Trend & 4 & -1.93 & 27.66 \\
\hline & Constant & 4 & -1.73 & 29.71 \\
\hline & None & 3 & 2.68 & \\
\hline \multirow{3}{*}{ prad95 } & Trend & 1 & -2.36 & 2.33 \\
\hline & Constant & 0 & 0.28 & 0.08 \\
\hline & None & 1 & -1.78 & \\
\hline \multirow[t]{3}{*}{ s } & Trend & 1 & -2.22 & $23.53^{*}$ \\
\hline & Constant & 1 & -0.89 & 28.69 \\
\hline & None & 1 & 0.90 & \\
\hline \multirow[t]{3}{*}{ sacind } & Trend & 0 & -0.67 & 2.02 \\
\hline & Constant & 0 & 1.75 & 3.08 \\
\hline & None & 2 & -0.63 & \\
\hline \multirow[t]{3}{*}{ ss } & Trend & 1 & -1.99 & 24.62 \\
\hline & Constant & 1 & -1.76 & 33.71 \\
\hline & None & 1 & 0.73 & \\
\hline \multirow{3}{*}{ unionind } & Trend & 0 & $-3.85^{* *}$ & $7.45^{*}$ \\
\hline & Constant & 1 & -0.57 & 3.15 \\
\hline & None & 0 & -1.55 & \\
\hline \multirow[t]{3}{*}{ wrateeppi } & Trend & 1 & -3.16 & 4.51 \\
\hline & Constant & 0 & -0.71 & 0.51 \\
\hline & None & 0 & 4.35 & \\
\hline \multirow[t]{3}{*}{ wrate } & Trend & 1 & -1.94 & 3.18 \\
\hline & Constant & 1 & -0.54 & 2.65 \\
\hline & None & 1 & $-2.79^{* *}$ & \\
\hline \multirow{3}{*}{ wsrateepti } & Trend & 0 & -1.25 & 1.28 \\
\hline & Constant & 0 & 0.13 & 0.02 \\
\hline & None & 0 & -1.88 & \\
\hline \multirow[t]{3}{*}{ wan } & Trend & 4 & 2.00 & 5.65 \\
\hline & Constant & 1 & -2.72 & $10.67^{* *}$ \\
\hline & None & 1 & 1.52 & \\
\hline \multirow{3}{*}{ avarate } & Trend & 1 & -0.78 & 2.52 \\
\hline & Constant & 1 & -1.78 & 3.59 \\
\hline & None & 1 & $-3.74^{* * *}$ & \\
\hline \multirow[t]{3}{*}{ watratepepi } & Trend & 1 & -3.13 & 4.41 \\
\hline & Constant & 0 & -1.22 & 1.47 \\
\hline & & 1 & $-2.27 *$ & \\
\hline
\end{tabular}

*(**) Significant at a $5(1) \%$ level.

a At a $5(1) \%$ significance level the MacKinnon critical values are $-3.56(-4.29)$ when a trend and a constant are included $\left(\tau_{\tau}\right)$, and $-2.96(-3.66)$ when only a constant is included $\left(\tau_{\mu}\right)$ and $-1.95(-$ 2.64) when neither is included $(\tau)$. The standard normal critical value is $-2.042(-2.704)$.

b At a $5(1) \%$ significance level the Dickey-Fuller critical values are $7.24(10.61)$ when a trend and a constant are included $\left(\Phi_{3}\right)$ and 5.18(7.88) when only a constant is included $\left(\Phi_{1}\right)$. 
Table A3. Augmented Dickey-Fuller tests for non-stationarity, first differenced, 1970-1999. (All data series in natural logarithmic form)

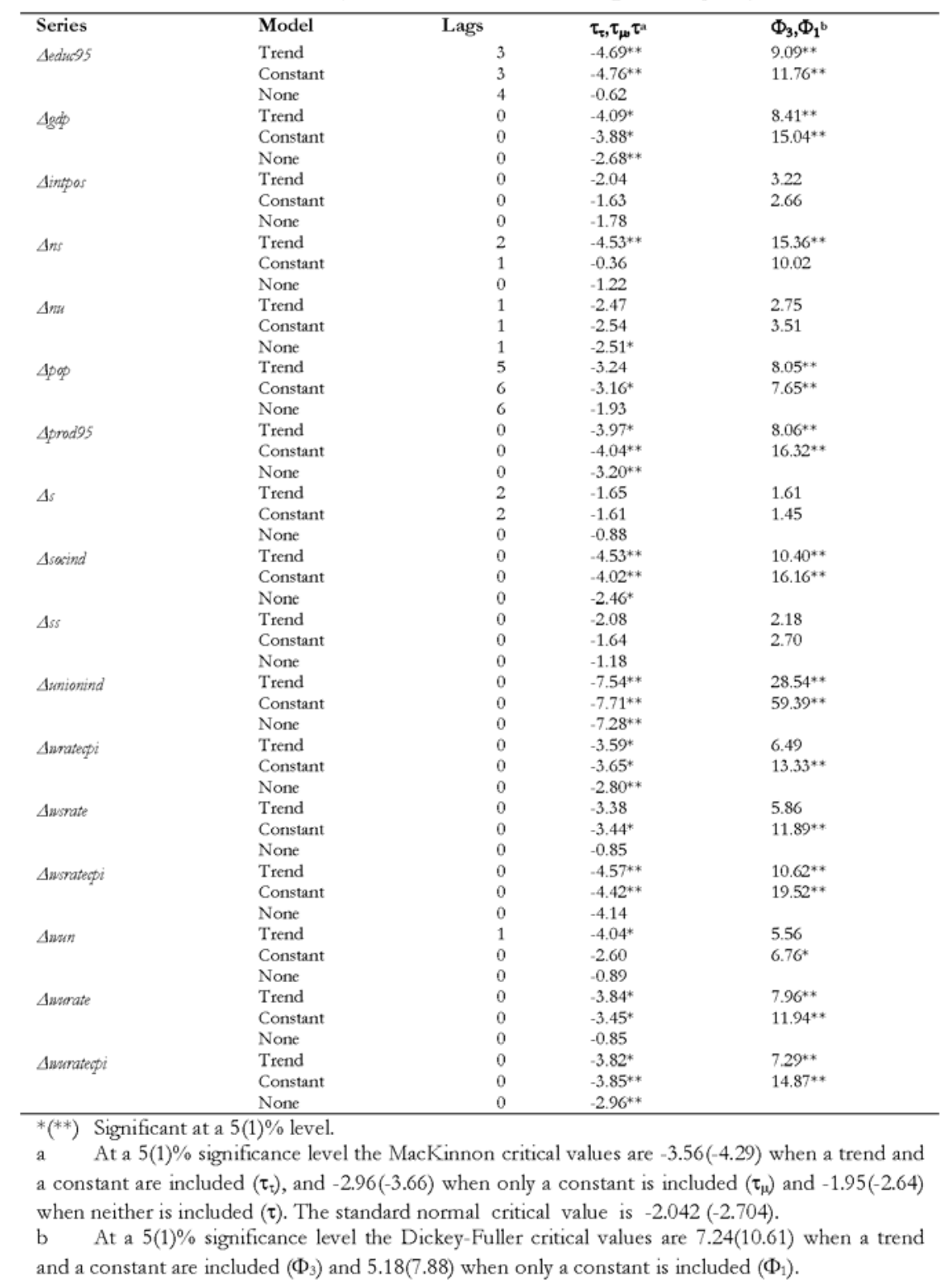




\section{REFERENCES}

ALLEN, C.B. (1997). A Supply-Side Model of the UK Economy: An Application of Non-Linear Cointegration. In Allen, C.B. and Hall, S.G. (Eds.), Macroeconomic Modelling in a Cbanging World: Towards a Common Approach. Chichester: John Wiley and Sons.

AND NixON, J. (1997). Two concepts of the NAIRU. In Allen, C.B. and Hall, S.G.

(Eds.), Macroeconomic Modelling in a Cbanging World: Towards a Common Approach. Chichester: John Wiley and Sons.

. AND URGA, G. (1995). Derivation and Estimation of Interrelated Factor Demands from a

Dynamic Cost Function. London Business School, Centre for Economic Forecasting Discussion Paper, No. 10-95.

Allen, C., HALL, S. G. AND NIXON, J. (1994). The New London Business School model of the UK economy. London Business School, Centre for Economic Forecasting Discussion Paper, No. $18-94$.

Bank OF ENGLAND, (2000), Economics Models at the Bank of England, September 2000 Update, Bank of England, London: 36-54.

BARKER, F.S. (1992). The South African Labour Market - Critical Issues for Transition. Pretoria: J.L van Schaik.

BERNDT, E.R. (1991). The Practice of Econometrics: Classic and Contemporary. New York: AddisonWesley Publishing Company. AND CHRISTENSEN, L.R. (1973). The Internal Structure of Functional Relationships:

Separability, Substitution, and Aggregation. Review of Economic Studies, 40: 402-10. . AND WOOD, D.O. (1975). Technology, Prices and the Derived Demand for Energy. Review of Economics and Statistics, 57: 259-68.

Budd, A., Dicks, G., Holly, S., KeAting, G. And Robinson, B. (1984). The London Business School Econometric Model of the UK. Economic Modelling, 1(4).

BUREAU FOR ECONOMIC POLICY AND ANALYSIS (BEPA). (1998). Improving the Labour Absorption Capacity of the South African Economy. Bepa Economic Paper, No. 29. Pretoria: University of Pretoria.

(1999). The Potential for Improving the Labour Absorption Capacity of SMMEs tbrough the Institutionalisation of the Informal Sector. Bepa Economic Paper, No. 30. Pretoria: University of Pretoria.

Burgess, D.F. (1974). A Cost Minimization Approach to Import Demand Functions. Review of Economics and Statistics, 56: 234-55.

CÔTÉ, D. AND HosTLAND, D. (1996). An Econometric Examination of the Trend Unemployment Rate in Canada. Working Paper, No. 96-7. Ottawa: Bank of Canada.

DARBY, J. AND WREN-LEWIS, S. (1993). Is there a Cointegrating Vector for UK Wages? Journal of Economic Studies, 20.

DOLADO, J.J., JENKINSON, J. AND SOSVILLA-RIVERO, S. (1990). Cointegration and unit roots: a survey, Joumal of Economic Surveys, 4, 249-76.

DowlING, M. (1997). Total Factor Productivity and Economic Growth - Issues for Asia. Paper presented at Project LINK, September 1997, Kuala Lumpur.

DU TOIT, C.B. (1999). A supply-side model of South Africa: critical policy implications. Doctorate thesis. University of Pretoria.

ElmeSKOV, J. AND MACFARLAN, M. 1993. Unemployment Persistence. OECD Economic Studies, No. 21. Paris: Organisation for Economic Co-operation and Development (OECD).

ENDERS, W. (1995). Applied Econometric Time Series, Wiley Series in Probability and Mathematical Statistics, John Wiley \& Sons, Inc., New York.

FALlEN, P. (1992). An Analysis of Employment and Wage Behaviour in South Africa. Southern A frican Division of the World Bank.. AND PERrEIRA DA SIlVA, L. (1994). South Africa - Economic Performance and Policies. Discussion Paper 7. Waskington: World Bank. 
FELIPE, J. (1997). Total Factor Productivity Growth in East Asia: A Critical Survey. Paper presented at Project LINK, September 1997, Kuala Lumpur.

GIBSON, B. (2000). Will lower wages cause faster growth? Journal for Studies in Economics and Econometrics, 24(3). Stellenbosch.

HALL, R.E. (1991). Labour Demand, Labour Supply, and Employment Volatility. In Blanchard,

O.J. and Fischer, S. (Eds.), NBER Macroeconomics Annual 1991. Cambridge: MIT Press. and Jones, C.I. (1996). The Productivity of Nations. NBER Working Paper Series, No. 5812. Cambridge: NBER.

HALL, S.G. (1995). Macroeconomics and a Bit More Reality. The Economic Joumal, July: 974-988.

- (1997). Modelling Economic Policy Responses. Paper presented at Project LINK, September 1997, Kuala Lumpur. (1997). Macroeconomic Modelling: A Perspective. In Allen, C.B. and Hall, S.G. (Eds.),

Macroeconomic Modelling in a Changing World: Tonards a Common Approach. Chichester: John Wiley and Sons. and Henry, S.G.B. (1985). Macweconomic Modelling. Amsterdam: North-Holland.

AND NixON, J. (1997). Modelling W ages and the Supply-Side of the UK Economy. Paper presented at Project LINK, September 1997, Kuala Lumpur.

HeLliWELl, J.F. (1986). Supply-Side Macro-Economics. The Canadian Journal of Economics, 19: $597-$ 625. (1995). Modelling the Supply Side: W bat are the Lessons from Recent Research on Gronth and Globalization? Paper presented at Project LINK, September 1995, Pretoria.

JOHANSEN, S. (1988). Statistical Analysis of Cointegration Vectors, Joumal of Economic Dynamics and Control, 12, 231-54

KLEIN, L.R. (1982). The Supply-Side of the Economy: A View from the Prospective of the Wharton Model. In Fink, R.F. (Ed.), Supply-Side Economics: A Critical Appraisal. Maryland: University Publications of America.

LAYARD, R. AND NICKELL, S. (1985). Unemployment, Real Wages and Aggregate Demand in Europe, Japan and the United States. Camegie Rochester Conference Series on Public Policy, 23: 143 202.

(1986). Unemployment in Britain. Economica, 53: S121-69.

NICKELL, S. AND JACKMANN, R. (1991). Unemployment, Macroeconomic Performance and the Labour Market. Oxford: Oxford University Press.

MaCKInNon, J.G. (1991). Critical values for cointegration tests, Department of Economics Discussion Paper No. 90-4, University of California, San Diego.

MANNING, A. (1992). Wage Setting, Productivity Growth and the Equilibrium Rate of Unemployment. London Business School, Centre for Economic Forecasting Discussion Paper, No.65. (1993). Wage Bargaining and the Phillips Curve: the Identification and Specification of

Aggregate Wage Equations. The Economic Journal, 103(416): 98-118.

(1995). Development in Labour Market Theory and their Implications for Macroeconomic Policy. Scottish Joumal of Political Economy, 42(3): 250-265.

NiCKELL, S. (1988). The Supply Side and Macroeconomic Modelling. In Bryant, R.C. et. al. (Eds.), Empirical Macroeconomics for Interdependent Economies. Washington: Brookings Institution: 202221.

PENCAVEL, J. (1985). Wages and Employment under Trade Unionism: Microeconomic Models and Macroeconomic Applications. Scandinavian Journal of Economic, 87(2).

PERRON, P. (1989). The great crash, the oil price shock, and the unit root hypothesis, Econometrica, 57(6), 1361-46.

PICHELMANN, K. AND SCHUH, A.U. (1997). The NAIRU-Concept: A Few Remarks. OECD Economics Department Working Papers, No. 178. Paris: Organisation for Economic Co-operation and Development (OECD).

ROSE, D.E. 1988. The NAIRU in Canada: Concepts, Determinants and Estimates. Technical Report, No. 50. Ottowa: Bank of Canada. 
SOUTH AFRICAN RESERVE BANK. Quarterly Bulletin, (various issues).

STOCK, J. AND WATSON, M. (1988). Testing for Common Trends, Joumal of the American Statistical Association 83 (Dec. 1988), 1097-1107.

THOMSEN, T. (1998). Links between Short- and Long-Run Factor Demand. Economic Modelling Working Paper Series, 1998:2.

TORRES, R. AND JARRETT, P. (1987). A Revised Supply Block for the Seven Major Seven Countries in Interlink. OECD Economics Department Working Papers, No. 41. Paris: Organisation for Economic Co-operation and Development (OECD).

TuRner, D., Richardson, P. AND RAUfFET, S. (1993). The Role of Real and Nominal Rigidities in Macroeconomic Adjustment, OECD Economic Studies, No. 21. Paris: Organisation for Economic Co-operation and Development (OECD).

- (1993). Modelling the Supply-Side of the Seven Major OECD Economies. OECD Economics Department Working Papers, No. 167. Paris: Organisation for Economic Co-operation and Development (OECD).

WALlis, K.F., Fisher, P.G., LONGBOTTON, J.A., TuRnER, D.S. And WhITLEY, J.D.(1987). Models of the UK Economy: A Fourth Review by the ESRC Macroeconomic Modelling Bureau. Oxford: Oxford University Press.

WHITLEY, J.D. (1994). A Course in Macroeconomic Modelling and Forecasting. Hertfordshire: Harvester Wheatsheaf. 